\author{
Yevhen SAVELYEV, \\ Halyna SMALYUK
}

\title{
ECONOMIC CONVERGENCE \\ IN THE EUROPEAN INTEGRATION SPACE IN THE CONTEXT OF RELATIONS BETWEEN UKRAINE AND THE VISEGRAD FOUR
}

\begin{abstract}
The problem of economic convergence of Ukraine is considered as a crucial way of reaching the goal of European integration and membership in the European Union. It takes into account the current economic situation in the country, the main feature of which is a significant lag behind all EU Member States, especially in terms of GDP per capita. The external factor is crucial in the concept because of the inability to singlehandedly accomplish convergence tasks in Europe and in the global space in a reasonable timeframe. The more substantial the changes, the more important the factors related to the development of international economic relations. The author's proposals concentrate on making economic convergence central in the development of overall convergence. Ukraine has great potential for mutually beneficial cooperation in all spheres with the Visegrad Four because it is a union of neighbouring countries and has gained

(C) Yevhen Savelyev, Halyna Smalyuk, 2019.

Savelyev Yevhen, Doctor of Economic Sciences, Professor, Professor at the Department of International Economics, Ternopil National Economic University, Ukraine. ORCID 0000-0003-01372263, RESEARCHERID H-6418-2017, yev.savelyev@gmail.com

Smalyuk Halyna, Candidate of Economic Sciences, Associate Professor, Associate Professor at the Department of International Economics, Ternopil National Economic University, Ukraine. ORCID 0000-0003-3963-8936, RESEARCHERID H-4195-2017, smalyukhalyna@gmail.com.
\end{abstract}



in the context of relations between Ukraine and the Visegrad Four

experience reducing a relatively large economic lag from the «old» EU members. The scope of the investigation is not limited to traditional forms of international cooperation, but is oriented towards new solutions. They are represented by the organizational model «V4 + UA» (Visegrad Four + Ukraine) with the prospect of developing into an enlarged association «Visegrad Five», which will continue to play the role of the internal structure of the European Union, and include a candidate for membership, i.e. Ukraine. Sustainable economic growth of a new group must rely on a unified market, Europe's greatest advantage, and concentrated structural reforms that can drive the production in the areas of growing demand. The author also admits the possibility of future establishment of confederate government in the model « $V 4+U A$ » in order to use the competitive advantages of large state entities such as Germany, France, Italy, Spain).

\section{Key words:}

Visegrad Five, Visegrad Four, diaspora, welfare, Europe's convergence machine, European Union, convergence, national convergence machine, labour migration, EU membership.

JEL: F15, F22, F43, J11, J61.

\section{Relevance of the research topic}

Problem statement. Integration in the modern world has become a major feature of globalization. In this process, nation-states are unified in intercontinental, continental and regional spaces through the creation of supranational institutions. The creation of integration associations is the result of solidarity mechanisms in action that balance the pursuit of different aspirations and interests by the parties. Therefore, integration empowers and develops a mechanism for closer cooperation between states, primarily in the economic sphere, as a basis for ensuring high-level equal conditions for the population of all members in the legal, social, cultural, environmental and other fields.

Ukraine, whose leaders hesitated between eastern and western integration vectors, has finally opted for European integration. The conclusion of the Association Agreement between Ukraine and the EU was the first step in this direc- 
ISSN 2519-4070

tion. The Agreement entered into force on September 1, 2017 and the free trade regime between the parties was established in 2016. The European integration direction of the foreign policy was documented in the Constitution in 2019 by the Verkhovna Rada of Ukraine. Although strategic decisions on European integration decisions at the political and supranational levels have been accelerating, the scientific development of the mechanism of their practical implementation is clearly lacking. The least attention is paid to the achievement of the developmental points that make it possible to raise the issue of membership in the European Union. In this context, the convergence of Ukraine in the European and global dimensions should be addressed first and foremost.

\section{Literature review and problem statement}

Among notable works are the analytical study by the Razumkov Centre ${ }^{1}$, evaluation of Ukraine's steps towards European integration by Sirenko K.Y. ${ }^{2}$, evaluation of the information strategy by Kostenko A.M. ${ }^{3}$, an annual report by "Society and Environment» Resource \& Analysis Center for $2018^{4}$. However, these publications focus on the general political aspects of Euro-integration. There is another group of publications that present the results of theoretical and methodological research of the European direction of integration. These include works by Ye. O. Kovalenko ${ }^{5}$, O. V. Sokur ${ }^{6}$, D. Slabykh ${ }^{7}$, Yu. Shcherbakova ${ }^{8}$.

\footnotetext{
${ }^{1}$ Sidenko, V. (2018). Reformatting European Integration: Opportunities and Risks for the EU-Ukraine Association. Kyiv, Zapovit, 214. URL: http://razumkov.org.ua/uploads/article/ 2018_pereformatuvannia_ievropeiskoi_intehratsii.pdf

${ }^{2}$ Sirenko, K. (2018). European integration policy of Ukraine: positive and negative aspects. Scientific Bulletin of Uzhhorod University, 22, 3. URL: http://www.visnykeconom.uzhnu.uz.ua/archive/22_3_2018ua/18.pdf

${ }^{3}$ Kostenko, A. (2018). Information and communication strategies of European integration in Ukraine. Almanac "Grani», 21, 11, 70-77. URL: file:///C:/Users/Sav/Desktop/1284Article\%20Text-2375-1-10-20190110.pdf

${ }^{4}$ "Society and Environment» Resource \& Analysis Center. (2019). Eurointegration as a goal. Kyiv. URL: http://www.rac.org.ua/uploads/content/518/files/webannualreport2018 eurointegrationua.pdf

${ }^{5}$ Kovalenko, Ye. (2008). Conceptual and methodological foundations of eurointegration policy. Humanities Bulletin of Zaporizhzhe State Engineering Academy, 32. URL: http://www.zgia.zp.ua/gazeta/visnik_32_210.pdf

${ }^{6}$ Sokur O. (2015). European integration: theoretical background and evolution of views. Topical Policy Issues, 55. 2015. URL: http://dspace.onua.edu.ua/bitstream/handle/11300/ 3231/\%D0\%A1\%D0\%BE\%D0\%BA\%D1\%83\%D1\%80\%20APP_55-6.pdf?sequence=1\&is Allowed $=\mathrm{y}$

${ }^{7}$ Slabykh D. (n.d.) Theoretical and methodological approaches to integration processes in Europe. URL: file:///C:/Users/Sav/Desktop/apdyo_2011_3_13.pdf

${ }^{8}$ Shcherbakova Yu. (2013). The values of a united Europe. Monograf. Kyiv, Publishing Centre «Academy». URL: http://www.enpuir.npu.edu.ua/bitstream/123456789/5183/1/zinnosti.pdf
} 

in the context of relations between Ukraine and the Visegrad Four

While the aforementioned areas of scientific investigations are undoubtedly important, it should be noted that in defining the strategic orientation towards European integration, efforts should be focused on developing tools to achieve the resulting goals, giving attention to those of highest priority first. Economic recovery is the key task for Ukraine, considering its current state of development. Moreover, its pace must ensure that it reaches European benchmarks, which above all requires the transition from annual to long-term development plans. The first steps in this direction were taken in 2019 when a program of government activity was developed, setting out goals and defining the main indicators of their achievement for a five-year period. This is in line with the requirements of the EU-Ukraine Association Agreement. However, the government's agenda does not yet set the challenge in the context of convergence, namely, the gradual rapprochement of the Ukrainian and European developmental levels, without which accession cannot be in question. In order to successfully overcome the contradictions of European integration, a system of step-by-step solutions must be determined aimed at achieving a certain level of macroeconomic criteria relative to the European average of population well-being.

Many scientific works of experts from European Union countries are devoted to the study of various problems of convergence. The convergence issue has been given some attention by IMF, World Bank, Centre for European Policy Studies (Brussels, Belgium), Leibniz Information Centre for Economics, Centre for European Policy Studies (CEPS) and others. There is no similar specialized infrastructure in Ukraine, although some scholars are turning to convergence issues. In particular, O. Bilous ${ }^{9}$, T. Burlai ${ }^{10}$, V. Vlasov, A. Hrytsenko ${ }^{11}$, I. Radionova, Ye. Alimiiev ${ }^{12}$, D. Lukianenko, V. Chuzhykov, V. Vozhniak ${ }^{13}$.

Ukraine's implementation of European integration policy implies that the experience gained by the EU countries should be taken as the basis for building a national model of convergence. It is a recognized and highly valued in developing countries. According to the World Bank, the European Union is the world's largest «Convergence Machine», which has helped the EU to achieve one of the world's highest levels of well-being and quality of life, as well as to strengthen its economic and social cohesion.

Ukraine's formation of a European-type national convergence machine should be based on the experience and model of EU convergence, as it allowed

\footnotetext{
${ }^{9}$ Belorus, O. (2015). Neo-convergence of socio-economic systems in the face of global challenges. Annual Journal of the Diplomatic Academy of Ukraine, 22 (3), 54-61.

${ }^{10}$ Burlai, T. (2019). Socio-economic convergence: theory and practice: Monograph. Kyiv, NAS of Ukraine; Institute for Economics and Forecasting, NAS of Ukraine, 364.

${ }_{11}$ Belorus, O., Vlasov, V., Hrytsenko, A. (2018). Global convergence-network financial economy: a monograph. Saarbrucken: LAP Lamden Academic Publishing, 632

${ }_{12}$ Macroeconomics-2: textbook. (2010). Growth in the process of economic convergence. Model of E. Gundlach. Kyiv, Kamianets-Podilskyi: Aksioma, 424, 252-273.

${ }^{13}$ Lukianenko, D., Chuzhykov, V., Vozhniak, M. (2010). Convergence of economic models of Poland and Ukraine: monograph. Kyiv, KNEU.
} 
ISSN 2519-4070

most new members of the group to move closer to the EU average, even though in the southern (old) unification countries this process slowed down. Poland, which outpaced other developing countries other than South Korea, was especially successful in joining the EU. Romania also developed successfully, with per capita income reaching $58 \%$ of the EU average in 2016 compared to $35 \%$ in $2005 .{ }^{14}$.

Candidate countries should consider the European Convergence Machine as an important component of the structural funds, which are oriented towards implementing a policy of rapprochement between developed and depressed regions. These funds are a fundamental basis in the convergence mechanism because they are in line with the EU's statutory purpose, namely the article 130a of the Single European Act (1986), which states «in order to promote its overall harmonious development, the Community shall develop and pursue its actions leading to the strengthening of its economic and social cohesion».

At the same time, structural funds should be created and used as a distributive and redistributive mechanism that directs financial inflows towards lagging regions and countries. This is especially true for the new Member States. Instead, the development of the richest and poorest member states of the Eurozone shows conflicting processes. On the one hand, they showed high growth rates in the precrisis period. On the other hand, the lag between the richest and poorest regions has increased ${ }^{15}$. Economic geography studies show deepening of integration processes through agglomeration effects in the production sector, which determines the concentration of incomes, and thus exacerbates regional differences ${ }^{16}$. This suggests that complete convergence of income is unrealistic. Against this background, future convergence policies should focus on ensuring cohesion and avoiding income polarization. Instead, it will need to be linked to an innovative territorial policy, which will focus on balancing processes of production concentration and territorial division of labour at regional and supranational levels.

\section{Research Aim}

The aim of the research is to identify the directions of economic divergence of Ukraine and its development in the context of cooperation with the Visegrad Four.

\footnotetext{
${ }^{14}$ Cinzia ,A., Bodewig, Ch., Preissl, B.(2018). Econonic convergence or divergence in the EU? CEPS. URL: https://www.ceps.eu/economic-convergence-or-divergence-in-the-eu/

${ }^{15}$ Alcidi, $_{2}$ C. (2019). Economic Integration and Income Convergence in the EU. Intereconomics. Review of European Economic Policy, 54, 1, 5. URL: https://archive.intereconomics.eu/ year/2019/1/economic-integration-and-income-convergence-in-the-eu/

${ }^{16}$ Stelmashchuk, A. (2016). Intrinsic characteristics, prerequisites and principles of crossborder convergence between Ukraine and the EU. Innovative Economy, 7-8 (64), 10. URL: http://nbuv.gov.ua/UJRN/inek_2016_7-8_3.
} 


\section{Research Findings}

Ukraine in the processes of European integration and economic convergence. The policy of European integration in Ukraine is developing controversially. On the one hand, the country is trying to develop a mechanism for implementing European values. On the other hand, there is a large proportion of the population that favours rapprochement with the Russian Federation. According to sociological polls, 59\% of Ukrainians prefer membership in the European Union, $19 \%$ prefer to join the Customs Union of the Russian Federation, Belarus and Kazakhstan ${ }^{17}$. At the same time, the EU does not have far-reaching anticipations for Ukrainian membership, despite co-operation in reform activities based on the implementation of European values. Nevertheless, the process is moving towards the choice of European integration. Instead, the Customs Union invites Ukraine into its fold «now and without conditions» to implement the Russian economic model by offering large long-term soft loans.

A characteristic feature of European optimists in Ukraine are the recent "cooling winds» from the western shores. An unfavourable backdrop for domestic political discourse is created by Germany and France facilitating the construction of the North Stream-2. Ukraine's EU integration prospects are wholly contradicted by the rejection of EU membership in Northern Macedonia and Albania solely because of the existence of unrelated internal unification issues (completely unrelated to membership aspirants). The French in the person of Macron insisted that «the EU should concentrate first and foremost on its own reforms before entertaining any further enlargement. He also called for a new methodology of accession negotiations ${ }^{18}$. Considering this position, there are reasons to consider his proposals as an invalidation of the conditions the fulfilment of which had been used for the accession of new countries to the EU.

Given the geopolitical and geo-economic processes of today and the crisis phenomena in the European Union, Ukraine, without losing sight of the strategic goal of European integration, should make achieving European standards of living and convergence the priority part of the EU accession aspirations. T. Burlai rightly points out that «launching and maintaining convergence processes is an indispensable condition for the full European integration of Ukraine, which ratified the Association Agreement with the European Union in September 2014 ${ }^{19}$. Therefore, convergence should be seen as an indirect method of unleashing the paradigm of meeting the goal of membership.

\footnotetext{
${ }^{17}$ Yevropeiska Pravda. (2019). 59\% of Ukrainians are in favor of joining the EU - polls. URL: https://www.eurointegration.com.ua/news/2019/07/10/7098320/

${ }^{18}$ Fouéré E. (2019). Macron's «non» to EU enlargement. URL : https://www.ceps.eu/ macrons-non-to-eu-enlargement/

${ }^{19}$ Burlai, T. (2019). Socio-economic convergence: theory and practice: Monograph. Kyiv, NAS of Ukraine; Institute for Economics and Forecasting, NAS of Ukraine, 3.
} 
Solving convergence problems for Ukraine involves first and foremost a focus on the economic component, as it ensures the formation of a sustainable and consistent development of the nation's well-being. As the main gauge of providing the population with goods and services is the indicator of gross domestic product per capita, the Ukrainian convergence machine must ensure that Ukraine at least reaches the level of the new countries of the European Union. This is a daunting task, given Ukraine's GDP per capita rating, which is lower than any EU country.

It is clear that convergence for developing countries entails competing with all the countries that have preceded them. However, in reality, the economic convergence strategy should be developed in view of those countries that have achieved the fastest progress in today's global economy. In this sense, Ukraine has an alternative - the Visegrad Four countries. First, V4 countries are significantly ahead of Ukraine in terms of GDP per capita, despite the fact that after the collapse of the communist bloc, the latter had higher rates. Secondly, the geographical proximity facilitates understanding of the fundamental success factors and their implementation and adapting them for the national characteristics of the country. Third, the neighbourhood ideology predominates the need for cooperation over market competition. Fourth, from the geopolitical point of view, the Visegrad countries as EU members do not have imperial ambitions unlike the eastern neighbour - the Russian Federation. In relation to the latter, it has a lower level of GDP per capita compared to V4 and is inferior to them in terms of economic development (Tables 1 and 2).

Therefore, it is possible to address economic convergence issues within the framework of stakeholder concepts. Although they are not sufficiently developed for the interstate level, methodological provisions on the expediency of determining "stakeholder composition, interest balance» may be acceptable for Ukraine's relations with $\mathrm{V}^{20}$. The willingness of the parties to make certain concessions in order to achieve the general purpose should be added to this. It is important to understand the balanced scale of mutually beneficial development in neighbourhood relations. This approach should be understood not as a collision of interests, but mostly as a resolution of the conflicts between them as a result of summing up, or perhaps even more precisely summarizing them.

For Ukraine, as for V4, in the context of convergence the most important task is to reduce the gap between developed countries. The main criterion for its measurement should be the welfare of the nation. The World Bank's conclusion is that «without taking into account the role of human capital as the most important component of its well-being, there can be no sustainable and consistent development of a nation ${ }^{21}$.

\footnotetext{
${ }^{20}$ Redchenko K. (2008). The influence of stakeholder theory on management accounting. Economy of Industry, 4, 60. URL: http://nbuv.gov.ua/UJRN/econpr_2008_4_9

${ }^{21}$ Karver J., Inchauste G. (2017). Perceptions of Welfare in the European Union. Beground to «Growing United: Upgrading Europe's Convergences Machine». World Bank Group, 3. URL: http://pubdocs.worldbank.org/en/927531520461248487/Perceptions-of-Welfare-in-the-EU.pdf; Levy, S., and M. Walton. (2005). No Growth without Equity: Inequality, Interests and Competition in Mexico. London: Palgrave Macmillan. URL: https://siteresources. worldbank.org/ INTMEXICOINSPANISH/Resources/nogrowthwithoutequity.pdf
} 
Table 1

Gross domestic product per capita in 2018 of V4 countries, Ukraine and Russia

\begin{tabular}{|c|c|c|c|c|c|c|}
\hline \multirow{3}{*}{ Country } & $\begin{array}{c}\text { constant prices as per } \\
\text { Purchasing power parity; } \\
\text { 2011 international dollar }\end{array}$ & \multicolumn{2}{|c|}{$\begin{array}{c}\text { current prices; } \\
\text { U.S. dollars }\end{array}$} & \multicolumn{2}{c|}{$\begin{array}{c}\text { current prices as per } \\
\text { Purchasing power par- } \\
\text { ity; international dollars }\end{array}$} \\
\cline { 2 - 7 } & $\begin{array}{c}\text { international } \\
\text { dollar 2011 }\end{array}$ & $\begin{array}{c}\text { Share of } \\
\text { Ukraine, } \\
\%\end{array}$ & U.S. dollars & $\begin{array}{c}\text { share of } \\
\text { Ukraine, } \\
\%\end{array}$ & $\begin{array}{c}\text { international } \\
\text { dollar }\end{array}$ & $\begin{array}{c}\text { share of } \\
\text { Ukraine, } \\
\%\end{array}$ \\
\hline $\mathrm{CZ}$ & $33,218,960$ & 24,8 & $22,850,316$ & 13,6 & $37,370,970$ & 24,8 \\
\hline $\mathrm{HU}$ & 28358,203 & 29,1 & $15,923,816$ & 18,6 & $31,902,671$ & 29,1 \\
\hline $\mathrm{PL}$ & 28390.196 & 29,1 & $15,430,927$ & 19,2 & $31,938,663$ & 29,1 \\
\hline $\mathrm{SL}$ & $31,226,781$ & 26,4 & $19,581,582$ & 15,1 & $35,129,791$ & 26,4 \\
\hline $\mathrm{RU}$ & $26,015,232$ & 31,7 & $11,326,773$ & 26,2 & $29,266,855$ & 31,7 \\
\hline $\mathrm{UA}$ & $8,252,020$ & $\star$ & $2,963,465$ & $\star$ & $9,283,433$ & $*$ \\
\hline
\end{tabular}

Source: Developed and calculated by the author based on World Economic Outlook Database, 2019. URL: https://www.imf.org/external/pubs/ft/weo/2019/02/weodata/weorept. aspx?pr. $\mathrm{x}=79 \& \mathrm{pr} . \mathrm{y}=7 \& \mathrm{sy}=2018 \& \mathrm{ey}=2018 \& \mathrm{scsm}=1 \& \mathrm{ssd}=1 \& \mathrm{sort}=$ country $\& \mathrm{ds}=. \& \mathrm{br}=1 \& \mathrm{c}=9$ 64\%2C935\%2C922\%2C936\%2C944\%2C926\&s=NGDPRPPPPC\%2CNGDPDPC\%2CPP PPC\&grp=0\&a $=($ Last accessed: 21.11 .2019$)$

Table 2

Gross domestic product, constant prices, Percent change

\begin{tabular}{|c|c|c|c|c|c|c|c|c|c|c|}
\hline State & $2000 /$ & $2001 / /$ & $2002 /$ & $2003 /$ & $2004 /$ & $2005 /$ & $2006 /$ & $2007 /$ & $2008 /$ & $2009 /$ \\
$\mathrm{S}$ & 2010 & 2011 & 2012 & 2013 & 2014 & 2015 & 2016 & 2017 & 2018 & 2019 \\
\hline \multirow{2}{*}{$\mathrm{CZ}$} & 4.267 & 2.909 & 1.652 & 3.603 & 4.907 & 6.533 & 6.854 & 5.603 & 2.682 & -4.803 \\
\cline { 2 - 12 } & 2.273 & 1.778 & -0.800 & -0.484 & 2.715 & 5.309 & 2.451 & 4.353 & 2.958 & 2.450 \\
\hline \multirow{2}{*}{$\mathrm{HU}$} & 4.209 & 3.841 & 4.528 & 3.849 & 5.005 & 4.388 & 3.851 & 0.422 & 0.851 & -6.601 \\
\cline { 2 - 11 } & 0.655 & 1.658 & -1.631 & 2.094 & 4.225 & 3.536 & 2.281 & 4.137 & 4.940 & 4.600 \\
\hline \multirow{2}{*}{$\mathrm{PL}$} & 4.260 & 1.205 & 1.443 & 3.562 & 5.136 & 3.494 & 6.180 & 7.035 & 4.250 & 2.820 \\
\cline { 2 - 11 } & 3.607 & 5.017 & 1.608 & 1.392 & 3.318 & 3.839 & 3.063 & 4.937 & 5.149 & 4.026 \\
\hline \multirow{2}{*}{$\mathrm{SL}$} & 1.210 & 3.316 & 4.523 & 5.419 & 5.259 & 6.751 & 8.453 & 10800 & 5.630 & -5.422 \\
\cline { 2 - 11 } & 5.042 & 2.819 & 1.657 & 1.491 & 2.750 & 4.175 & 3.125 & 3.188 & 4.109 & 2.60 \\
\hline \multirow{2}{*}{$\mathrm{RU}$} & 10.046 & 5.090 & 4.744 & 7.349 & 7.176 & 6.376 & 8.154 & 8.535 & 5.248 & -7.821 \\
\cline { 2 - 10 } & 4.550 & 5.066 & 3.700 & 1.800 & 0.700 & -2.308 & 0.329 & 1.630 & 2.255 & 1.084 \\
\hline \multirow{2}{*}{$\mathrm{UA}$} & 5.932 & 5.209 & 5.300 & 9.500 & 11.800 & 3.100 & 7.600 & 8.200 & 2.200 & -15.100 \\
\cline { 2 - 10 } & 4.100 & 5.466 & 0.239 & -0.027 & -6.553 & -9.773 & 2.441 & 2.525 & 3.277 & 2.990 \\
\hline
\end{tabular}

Source: Developed by the author based on: World Economic Outlook Database, 2019. URL: https://www.imf.org/external/pubs/ft/weo/2019/02/weodata/weorept.aspx?pr.x=41\& pr. $. y=5 \&$ sy $=2000 \& e y=2019 \& s c s m=1 \& s s d=1 \&$ sort $=$ country $\& d s=. \& b r=1 \& c=964 \% 2 C 935 \% 2$ C922\%2C936\%2C944\%2C926\&S=NGDP_RPCH\&grp=0\&a= (Last accessed: 3.12 .2019$)$ 
Balancing this problem at the interstate level should and will take into account the differences in each country when measuring GDP per capita. It is the most important and most integrated criteria for assessing the well-being of the nation. Sustainable and consistent development through GDP per capita is a reflection of the success of a long-term human capital policy, including the extremely important aspects of Ukraine's ease of doing business, fertility, education, healthcare, quality longevity. Well-being measures generate confidence among citizens as consumers and investors and lead to behaviour that intensifies reform efforts, especially for those who are traditionally unpopular with the active opposition. The 2019 presidential and parliamentary elections in Ukraine testify to citizens' dissatisfaction with the current state of the economy and social justice. Therefore, the indiscriminate enforcement of fairness in the social sphere should be the prerequisite for the successful continuation of economic reforms initiated by the former government in the context of increasing confidence in them. Research on convergence problems by the World Bank ${ }^{22}$ suggests that it is on this basis that we can count on the success of land, fiscal and other reforms.

Many European experts make the right conclusion that to replace the current "convergence machine», it is necessary to develop a "convergence machine-2». However, a new machine is being developed for the leading countries to accelerate their growth rate.

Ukraine, as well as developing countries in general, needs a different strategy. It must open up its technological borders; make itself attractive to countries that are unable to sustain high growth rates per capita without expanding their technological borders. The country needs to develop a system of returning its graduates from foreign universities along with foreign and domestic investors to their homeland. It can have financial, technical, entrepreneurial, temporal and personal components.

The problematic trend of European integration is that the EU is growing, but Europeans are not "growing united". The solution is that the convergence machine in version 2.0 should become the convergence machine of people and firms across the Union ${ }^{23}$. The likelihood of such a decision being successful is low due to the inability of everyone to become leaders equally. Ukraine should take into account the greatest value of Europe in the process of implementing the European integration strategy - a unified market with high solvent demand. Targeting this market «unleashes» structural reforms in areas that, for advanced economies, should begin with immediate, rather than gradual "destruction» of traditional industries. This is most evident in the agrarian sector, which has the potential to capture the European healthy food market instantly and, with experience and capacity, move to other markets.

22 World Bank Group. (2017). World Development Report 2017: Governance and the Law. Washington, DC: World Bank. URL: https://openknowledge.worldbank.org/handle/10986/ 25880

${ }^{23}$ Alcidi C., Bodewig Ch., Preissl B. (2018). Economic convergence or divergence in the EU? CEPS. URL: https://www.ceps.eu/economic-convergence-or-divergence-in-the-eu/ 
Table 3

Labour migrants from Ukraine by country of residence, sex and place of residence before departure abroad (2015-2017), thousand people ${ }^{24}$

\begin{tabular}{|l|c|c|c|c|c|}
\hline & Total & Women & Men & Urban & Rural \\
\hline $\begin{array}{l}\text { Number of migrant work- } \\
\text { ers, total, thousand }\end{array}$ & 1303,3 & 385,8 & 917,5 & 663,5 & 639,8 \\
\hline $\begin{array}{l}\text { including by country of } \\
\text { residence, \% }\end{array}$ & & & & & \\
\hline Poland & 38,9 & 42,6 & 37,3 & 38,3 & 39,5 \\
\hline Russian Federation & 26,3 & 15,1 & 31,0 & 33,0 & 19,3 \\
\hline Italy & 11,3 & 27,0 & 4,7 & 7,3 & 15,4 \\
\hline Czech Republic & 9,4 & 6,2 & 10,7 & 5,2 & 13,7 \\
\hline Hungary & 1,3 & 0,9 & 1,5 & 1,2 & 1,5 \\
\hline
\end{tabular}

Source: Compiled by the author based on data of State Statistics Service of Ukraine, 2017.

V4 countries should become partners in the implementation of the convergence strategy, because the economy of its countries is mostly dependent on the Ukrainian labour market. As shown by Ye. Savelyev, V. Kuryliak and M. Kuryliak, "The tendency of shifting the priorities of migrant workers from the Russian direction to the European one is important for the development of cooperation between Ukraine and the V4 countries, although the Russian Federation remains among the major countries of their stay. At the same time, V4 countries are among the most attractive to migrant workers from Ukraine. Among all countries of the world, Ukrainian migrant workers prefer Poland. It provides jobs to $38.9 \%$ of Ukrainian migrant workers. The share of Czech Republic among labour migrants from Ukraine is $9.4 \%$ (fourth place after the Russian Federation and Italy), Hungary $-1.3 \%$ (eighth place after Poland, the Russian Federation, Czech Republic, USA, Belarus and Portugal) ${ }^{25}$ (Table 3 ).

The territory of the Visegrad Four and Ukraine is $1137237 \mathrm{~km}^{2}$, of which $53.1 \%$ belong to Ukraine. The way in which the labour market in this territory is developing in the relations "V4 - UA» is not natural. It became an action to create Ukrainian diasporas as a result of labour imports from Ukraine. In recent decades, powerful Ukrainian diasporas have formed in the V4.

\footnotetext{
${ }^{24}$ State Statistics Service of Ukraine. (2017). Labour emigration of the population (according to the results of the modular sampling survey). Kyiv, 8.

${ }^{25}$ Savelyev, Ye., Kuryliak, V., Kuryliak, M. (2019). The Visegrad Four and Ukraine in the Context of the Development of European Integration Processes. Economic Herald of the Donbass, 3, 25
} 
These processes depopulate the Ukrainian people. No matter how economically good it may be for the neighbouring countries, it also creates a new ethnic situation, which gives rise to long-lasting problems of difficult-to-solve national-cultural relations. An alternative to this path is the formation of a common economic space that functions and develops in the terrestrial, freshwater and marine ecosystems with a person as a central character, not given to any politically sovereign state unit in the current historical time. As K. Georgieva rightly points out in the publication entitled «The Adaptive Age", "When I think of the incredible challenges we must confront in the face of a changing climate, my mind focuses on young people. Eventually, they will be the ones either to enjoy the fruits or bear the burdens resulting from actions taken today. I think of my 9-yearold granddaughter. By the time she turns 20 , she may be witness to climate change so profound that it pushes an additional 100 million people into poverty. By the time she turns 40, 140 million may become climate migrants-people forced to flee homes that are no longer safe or able to provide them with livelihoods. And if she lives to be 90 , the planet may be $3-4$ hotter and barely liveable» ${ }^{26}$. From this perspective, globalization, as well as its manifestation of international regionalization, contribute to the dissemination of «knowledge and technology across borders...In emerging markets, the transfer of technology has helped to boost innovation and productivity even in the recent period of weak global productivity growth» ${ }^{27}$.

\section{Conclusion}

Looking to the future, Central Europe is a political entity without economic frontiers. It can be expanded as V4 = UA or as Visegrad Five. It is not yet time, but one cannot exclude the possibility of creating a confederation-type association on the scale of the Federal Republic of Germany, France, Italy or Spain. There are certain resource volumes without which a manufacturing economy (not a financial-banking economy) can compete with today's European leaders. The tensions and historical and ethnic divisions in the Balkans are not eternal. And Russia will not untie the "Gordian knots» on the European continent, as there is still much to transform in its Eurasian territories. The smaller ones in Europe, without losing their existing borders, are building new borders. However, the slogan «Europe without borders» is not yet the case. The individualities in Central and Eastern Europe are not so far removed that they do not come closer to keep up.

${ }^{26}$ Georgieva K. (2019). The Adaptive Age. IMFBlog. URL: https://blogs.imf.org/2019/ 12/02/straight-talk-the-adaptive-age/?utm_medium=email\&utm_source=govdelivery

${ }^{27}$ Aslam A., Giang Ho J., Osorio-Buitron C., Piazza R. (2019). Globalization Helps Spread Knowledge and Technology across Borders. IMFBlog. URL: https://blogs.imf.org/2018/ 04/09/globalization-helps-spread-knowledge-and-technology-across-borders/?utm_medium =email\&utm_source=govdelivery 

in the context of relations between Ukraine and the Visegrad Four

Europe is the territory of the birth and development of a new civilization, the basis of which is integration. It is becoming the birthplace of new forms of coexistence between peoples, economic and financial relations, interaction with the environment. Europe has developed its own convergence model, which has led to the creation of an integrated union of 27 states and other aspirants for membership. Ukraine's task is to create a national convergence machine that adapts the European version to its own conditions and tasks.

\section{References}

1. Belorus, O., Vlasov, V., Hrytsenko, A. (2018). Global convergence-network financial economy: a monograph. Saarbrucken: LAP Lamden Academic Publishing, 632.

2. Belorus, O. (2015). Neo-convergence of socio-economic systems in the face of global challenges. Annual Journal of the Diplomatic Academy of Ukraine, 22 (3), 54-61.

3. Burlai, T. (2019). Socio-economic convergence: theory and practice: Monograph. Kyiv, NAS of Ukraine; Institute for Economics and Forecasting, NAS of Ukraine, 364.

4. State Statistics Service of Ukraine. (2017). Labour emigration of the population (according to the results of the modular sampling survey). Kyiv, 8

5. «Society and Environment» Resource \& Analysis Center. (2019). Eurointegration as a goal. Kyiv. URL: http://www.rac.org.ua/uploads/ content/ 518/files/webannualreport2018eurointegrationua.pdf

6. Yevropeiska Pravda. (2019). 59\% of Ukrainians are in favor of joining the EU - polls. URL: https://www.eurointegration.com.ua/news/2019/07/10/7098320/

7. Macroeconomics-2: textbook. (2010). Growth in the process of economic convergence. Model of E. Gundlach. Kyiv, Kamianets-Podilskyi: Aksioma, 424, 252-273.

8. Kovalenko, Ye. (2008). Conceptual and methodological foundations of eurointegration policy. Humanities Bulletin of Zaporizhzhe State Engineering Academy, 32. URL: http://www.zgia.zp.ua/gazeta/visnik_32_210.pdf

9. Lukianenko, D., Chuzhykov, V., Vozhniak, M. (2010). Convergence of economic models of Poland and Ukraine: monograph. Kyiv, KNEU

10. Kostenko, A. (2018). Information and communication strategies of European integration in Ukraine. Almanac «Grani», 21, 11, 70-77. URL: file:///C:/Users/Sav/Desktop/1284-Article\%20Text-2375-1-10-20190110.pdf 
11. Sidenko, V. (2018). Reformatting European Integration: Opportunities and Risks for the EU-Ukraine Association. Kyiv, Zapovit, 214. URL: http://razumkov.org.ua/uploads/article/2018_pereformatuvannia_ievropeiskoi intehratsii.pdf

12. Redchenko K. (2008). The influence of stakeholder theory on management accounting. Economy of Industry, 4, 60. URL: http://nbuv.gov.ua/UJRN/ econpr_2008_4_9

13. Savelyev, Ye., Kuryliak, V., Kuryliak, M. (2019). The Visegrad Four and Ukraine in the Context of the Development of European Integration Processes. Economic Herald of the Donbass, 3, 25

14. Sirenko, K. (2018). European integration policy of Ukraine: positive and negative aspects. Scientific Bulletin of Uzhhorod University, 22, 3. URL: http://www.visnyk-econom.uzhnu.uz.ua/archive/22_3_2018ua/18.pdf

15. Slabykh D. (n.d.) Theoretical and methodological approaches to integration processes in Europe. URL: file:///C:/Users/Sav/Desktop/apdyo_2011_3_13.pdf

16. Sokur O. (2015). European integration: theoretical background and evolution of views. Topical Policy Issues, 55. 2015. URL: http://dspace.onua.edu.ua/ bit-

stream/handle/11300/3231/\%D0\%A1\%D0\%BE\%D0\%BA\%D1\%83\%D1\%80 \%20APP_55-6.pdf? sequence $=1$ \&isAllowed $=y$

17. Stelmashchuk, A. (2016). Intrinsic characteristics, prerequisites and principles of cross-border convergence between Ukraine and the EU. Innovative Economy, 7-8 (64), 10. URL: http://nbuv.gov.ua/UJRN/inek_2016_7-8_3.

18. Shcherbakova Yu. (2013). The values of a united Europe. Monograf. Kyiv, Publishing Centre «Academy». URL: http://www.enpuir.npu.edu.ua/ bitstream/123456789/5183/1/zinnosti.pdf

19. Alcidi, C. (2019). Economic Integration and Income Convergence in the EU. Intereconomics. Review of European Economic Policy, 54, 1, 5. URL: https://archive.intereconomics.eu/year/2019/1/economic-integration-andincome-convergence-in-the-eu/

20. Aslam A., Giang Ho J., Osorio-Buitron C., Piazza R. (2019). Globalization Helps Spread Knowledge and Technology across Borders. IMFBlog. URL: https://blogs.imf.org/2018/04/09/globalization-helps-spread-knowledge-andtechnology-across-borders/?utm_medium=email\&utm_source=govdelivery

21. Cinzia, A., Bodewig, Ch., Preissl, B.(2018). Econonic convergence or divergence in the EU? CEPS. URL: https://www.ceps.eu/economic-convergenceor-divergence-in-the-eu/

22. Alcidi C., Bodewig Ch., Preissl B. (2018). Economic convergence or divergence in the EU? CEPS. URL: https://www.ceps.eu/economic-convergenceor-divergence-in-the-eu/ 

in the context of relations between Ukraine and the Visegrad Four

23. Georgieva K. (2019). The Adaptive Age. IMFBlog. URL: https://blogs.imf.org/ 2019/12/02/straight-talk-the-adaptive-age/?utm_medium=email\&utm_source =govdelivery

24. Karver J., Inchauste G. (2017). Perceptions of Welfare in the European Union. Beground to «Growing United: Upgrading Europe's Convergences Machine». World Bank Group, 3. URL: http://pubdocs.worldbank.org/en/ 927531520461248487/Perceptions-of-Welfare-in-the-EU.pdf;

25. Levy, S., and M. Walton. (2005). No Growth without Equity: Inequality, Interests and Competition in Mexico. London: Palgrave Macmillan. URL: https://siteresources.worldbank.org/INTMEXICOINSPANISH/Resources/nogr owthwithoutequity.pdf

26. Fouéré E. (2019). Macron's «non» to EU enlargement. URL: https://www.ceps.eu/ macrons-non-to-eu-enlargement/

27. World Bank Group. (2017). World Development Report 2017: Governance and the Law. Washington, DC: World Bank. URL: https://openknowledge. worldbank.org/handle/10986/2588 